\title{
Funding Challenges Facing SMEs' Growth in Lebanon
}

\author{
Riad Makdissi*, Jimmy Tannous \\ Finance Department, Faculty of Economics and Business Administration, Lebanese University, Tripoli, Lebanon
}

Email address:

Riad.makdissi@ul.edu.lb (R. Makdissi),Jim_t94@hotmail.com(J. Tannous)

${ }^{*}$ Corresponding author

\section{To cite this article:}

Riad Makdissi, Jimmy Tannous. Funding Challenges Facing SMEs' Growth in Lebanon. International Journal of Business and Economics Research. Vol. 9, No. 1, 2020, pp. 50-59. doi: 10.11648/j.ijber.20200901.16

Received: January 28, 2020; Accepted: February 11, 2020; Published: February 14, 2020

\begin{abstract}
Building the capacity of small and medium-sized enterprises is at the heart of the concerns of modern economies. These types of enterprises are the engine of growth through the creation rate, explained by the low level of investment they require, the level of job creation and the low level of technology that gives them adaptability to Changes. In most developing countries, the problem of funding is common for SMEs. The funding challenge is the main barrier to the growth of SMEs, either due to lack of internal or external funds or due to the difficulty of the processes to be followed for loans' approval. What is most worrying in Lebanon is that SMEs are fundamentally opportunities to get out of underdevelopment. Today, banks are finding it extremely difficult to finance SMEs in terms of the problems of informalities, weak guarantees and low capitalization. SMEs represent a significant share of banks' customers; that is why banks need to give more attention to the SME sector, seeking to meet at its best their needs and expectations. A survey was carried out on a sample of 110 Lebanese SMEs working in different regions in Lebanon and in various sectors. In addition to the questionnaire, we met qualified bankers from the five top leading banks in Lebanon to highlight lending requirements and procedures, risk assessment and management, approval and rejection decisions related to loans. As a result, limitation of access to funds were mentioned with different ways of solutions, requesting a real support and cooperation between actors: public authorities, central bank, financial institutions and SMEs.
\end{abstract}

Keywords: SME, Financing, Funding, Challenges, Banks, Lebanon

\section{Introduction}

As the global economy may be beginning to recover from the worst financial and economic crisis in decades, governments, businesses and consumers continue to face significant challenges on the road to prosperity [1].

Small and medium-sized enterprises (SMEs) and entrepreneurs must maintain their central place in national strategies for growth, job creation and social cohesion [2]. Because of their role in the development and dissemination of innovations, SMEs and entrepreneurs are crucial to charting new paths to more sustainable and inclusive growth [3]. However, this potential could be realized if they have the funds to launch and grow [4].

The structural view of the economic situation of poor countries in general and Lebanon in particular, show that they are all fighting for better economic and social development. That is why political independence must necessarily follow economic independence [5].

The choice for large industrial companies did not meet expectations when manufacturing was included in the development goals [6]. It is therefore necessary to develop SMEs that are capable of strengthening the national economy and giving new impetus. This category of companies is not very capitalist, but its contribution to employment is interesting, especially in a country like Lebanon where the problem of unemployment increases every year, it allows the decentralization of investments, mobilization private savings, therefore promote localization and finally, streamline production by reducing costs, allowing better competition from the economy in foreign markets.

Although the role of SMEs is important, it suffers from many problems in Lebanon; among them are the problem of access to bank financing and the low level of technology that makes them adaptable to change [7].

Two fundamental aspects are now a question of financing 
SMEs. The first one, banks with liquidity have enormous difficulties in financing SMEs, in particular because of problems of "informalities", weak guarantees and low capitalization in SMEs. The second one, MFIs (Micro Finance Institution), that have more flexible financing mechanisms, have great difficulty in meeting the financing needs of small businesses [8]. This clearly shows that the weakness of the banks is the strength of MFIs and vice versa.

In the two previous aspects, is there any real financial institution that can grant them facilities or provide them with the funds needed to solve funding problems?

From this central question, arise the following sub-questions: What are the other factors that limit the financing of SMEs? What should the Lebanese government do to encourage such initiatives, in particular to improve the financial situation of SMEs?

\section{Literature Review}

The relationship between the bank and the company is often a complex relationship based on imperfect and incomplete information [9]. The granting of credit as well as information are essential elements of the banking sector, each credit problem stems mainly from the information asymmetry, which exists between lenders and borrowers, this leads to consequences results in credit rationing or extremely high interest rates [10]. Indeed, a credit is a decision that is both irreversible and risky. The quality and profitability of investments are linked to an uncertain future, as well as to the current situation [11]. In these situations of information asymmetry, the agency's theory then evolved with the founding essay of Jensen and Meckling (1976).

The theoretical approach allowed us to focus on different concepts, through ideas led by some authors on the bank-to-enterprise relationship. This relationship requires compliance with banking requirements [12]. The principal (the bank) can mitigate the negative effects of differences in interest with the agent (company) through appropriate incentives and controls [13].

Growth and development policies are often based on the growth of production and marketing capital. This growth is the result of a set of investment decisions, i.e. the need for money for the creation of a financial asset.

The funding plan is based on credible assumptions that offer the best chance of success of the project. It is a multi-year forecast table, allowing identifying all the structural financial needs and resources of a company (any economic agent: households, government... can draw up a funding plan). The financing plan does not allow for a financial analysis, but it will measure the impact of an investment plan on the economic and financial life of the company and assess the feasibility of the project [14].

The enterprise needs to invest to ensure its development (investment needs). These may be investments in physical or intangible goods. It could engage four types of investment-making actions: alternative investments, rationalization investments, human and social investments, and creative investments. The company needs capital to finance its operation (operating needs): buy materials, store them, process them, and store finished products. The longer the operating cycle, the greater the financing needs. Businesses need to innovate to grow and meet market needs (innovation needs). Innovation is a way to achieve strategic goals, improve competitiveness, differentiate and create value [15].

In Lebanon, SMEs financial structures are weak; their development and financial stability are far from being acquired. SMEs face a difficult business environment, acknowledged by Najib Choucair, Executive Director of the Banking Department in the Lebanese Central Bank for the past 25 years. SMEs use not only their own resources (self-financing, capital increase), but also external resources (banking resources) to finance their long- and medium-term growth [7].

In order to convince investors, the entrepreneur must first develop a business plan presenting the company and its strategy. The business plan, generally seen as the presentation of a company's future, is an essential document when it comes to starting a business [16]. It will contain: an operational summary that presents a summary of the project, an analysis of the economic environment in which the project is part, a study of actual and potential competitors and the market, a description of the characteristics of the product or service, a description of human resources, an analysis of the risks and opportunities of the project.

The corporate financier must adapt his reflexes to negotiate with the various economic partners: monitor the markets to seize opportunities, manage the assets constantly, and develop a dynamic relationship with intermediaries Financial. These new financial transactions contribute to the development of the image of companies abroad for this; the financial function is a precursor of the commercial function that will be indispensable for the future development of the firm.

The choice of investment financing is in a more or less difficult economic context. Variable financing costs must be taken into consideration by the business's manager. Every company must reflect on its financing policy, which should enable it to finance it at a lower cost, while maintaining a balanced financial situation, in order to ensure its growth and sustainability. Whether the type of funding: internal or external, debt or equity, long-term or short-term, may have different effects on financial performance. Owners managing SMEs preferred internal financing to external financing, since external financing requires clearer contractual terms. It is important to note, however, that the long-term needs of the company must be financed by long-term resources and equally for short-term jobs that must be financed by short-term resources [17].

Financing of investments through bank borrowing is still the most privileged mode of financing. There are many reasons why companies should negotiate with their bankers. This type of financing has its constraints, which are expressed in terms of cost, debt limits and repayment capacity. These 
limits result in a level of dependency acceptable to both parties [18]. You have to choose the right time, know the negotiable offers and documents that may be required and the processing time.

All players seek to avoid the default of the business by the inability to pay its debts, which is a serious event. This is why a lot of research has been done to prevent this accident through forecasting. The default forecasting models are also a decision-making tool for investors who determine the probability of a firm going bankrupt, taking control, or investing [19]. This forecast is of great importance to creditors who are at risk of losing the debt in the case of a bankruptcy. The use of business bankruptcy forecasting models may vary according to the tools and methodologies used, the sample selected, the explanatory variables chosen and the method of validation of results.

Globalization, the new economy, trade liberalization, increased competition, crises, and financial and monetary uncertainties force companies to take into account and manage financial risks that invade the company, including in its domestic activities. Risk is a matter of chance. This is the probability that an uncertain event will occur, the effects of which will be harmful or cause loss. Generally, risk covers many areas of technology, commercial, managerial, social, political and financial firms, etc., national and international [20].

Financial risk management, despite its specificity, affects the firm's overall policy. The two main interesting risks are related to changes in exchange rates and fluctuations in interest rates. Exchange is the price of a reference currency denominated by another currency. The foreign exchange risk is the variation in the exchange rate. Foreign exchange risk affects all companies whose balance sheet items are denominated in foreign currency and must be converted at a given time into national currency, which is the case of Lebanon where the economy is dollarized as declared by Riad Salame, the Central Bank's governor [21]. Interest rate risk is the exposure of a lender or borrower to a change in the interest rate (investment remuneration or borrowing cost) that would result in an increase in the cost of borrowed resources or a loss of profits on an investment [20].

The government is an important factor in the business environment [22]. It can be a customer of companies and order them: the companies then become the suppliers of the government. Monetary policy is all the means at the disposal of governments or monetary authorities (the central bank) to influence economic activity through monetary supply. The objective is to ensure price stability, which plays an important role in the development of economic activity. Central banks' main policy instruments: the exchange rate, the discount rate, the intervention in the money market, set authoritatively the amount of credits that banks can grant [23].

The government implements fiscal policy to influence the country's economy by using its power to set government revenues and priorities in the allocation of public spending. For example, the government can offset a slowdown in private demand by increasing public spending to stimulate the economy, and the government must reduce the public deficit when economic growth is high [22]. The main levers of fiscal policy are government revenues and spending. A large issue of public debt securities competes with firms in the capital market, leading to higher interest rates and the exclusion of investors. These effects may result from changes in interest rates or inflation.

Tax policy is the set of decisions made regarding government spending and the tax rules put in place by the government. Through fiscal policy, governments must guarantee sufficient budgetary revenues to ensure the sustainability of activities of general interest and to promote the expansion of the economy. It must have a simple, fair, efficient and competitive tax system for taxpayers and businesses. The creation of a stable and competitive business environment conducive to the vitality and growth of the economy comes from an effective tax policy. Indeed, corporate taxation has an impact on investors' decisions and thus on economic growth and employment. A complex and excessive tax discourages foreign investors, alienates domestic investors, inhibits entrepreneurship and causes dry losses due to the tax cost [24].

There is no single definition of SMEs; definitions vary according to the laws or regulations and from country to country due to the incompatibility of the size of the economy at the international level. In general, an SME has less than 500 employees; but in many countries, the level varies between 100 and 300 employees. Two types of identification criteria are traditionally distinguished. The first ones, the quantitative criteria are numerous and related to the different elements of the business activity. These are numbers of people, turnover, added value, social capital, location and market. The second ones, qualitative criteria are used not only to support the former, but also to give a precise idea of the SME, since they provide information on its internal structure, organization and management methods. The basic criterion for defining SMEs in developing countries is that of employment. They have a major concern to deal with the problem of unemployment that is becoming more important over time. Thus, most definitions of SMEs in developing countries take into consideration the demographic factor, i.e. the number of jobs created per enterprise [25].

Nowadays, society is undergoing profound challenges, driven fundamentally by technological, economic and social developments. Small and medium-sized enterprises (SMEs) are a major source of employment and wealth [26]. However, despite these strengths, SMEs suffer from a set of weaknesses that obstruct their development and sustainability [27].

Strengths:

1. Flexibility: It is the ability to adapt quickly to environmental changes.

2. Efficiency: Low structural costs for SMEs.

3. The quality and simplicity of social relations: The small size of SMEs allows them to manage their employees more efficiently and cost effectively.

Weaknesses:

1. The main difficulty for SMEs is the source of fund 
(instability of their self-financing, etc.)

2. Leader role: Lack of experience in the field of Finance, Marketing, Accounting, etc.

3. Longer payments terms to customers v/s much shorter time to pay suppliers.

4. Fear of working in the "clear"

5. Lack of competitiveness factors: do not possess the means (human, financial, material)

Small and medium-sized enterprises have an important place in both developed and under development countries. SMEs are an excellent way to create a generation of national entrepreneurs, and they can launch and consolidate an adopted economic fabric to the needs of the country. SMEs are one of the most dynamic elements of economic and social growth in each country's development strategy [28].

Social role:

1. Job creation: Employment creation is a major problem worldwide. Small and medium-sized enterprises use production techniques that rely heavily on local labor, and will create more jobs than large enterprises.

2. Economic role:

3. Production, consumption and export: Production growth is possible with several small and medium-sized enterprises in various fields. Even though the SME is only a small production unit, the overall production of each SME in its area is capable of achieving some self-sufficiency, so the expansion of the SME greatly improves exportation. Generally, when production is good, consumption is also linked to self-sufficiency, the surplus can be exported and the foreign currencies will be introduced into the country's economy.

4. Tax matters: The government's tax system is closely linked to its economic structures. Indeed, to cover public expenditures, the tax system aims to obtain the necessary resources from the nation's income. The tax levy will not be a big problem, since its managing way is not as complicated as in corporate enterprises.

5. The fight against inflation: Inflation is the general rise in prices after an excessive increase in the money supply in circulation. By placing goods and services on the market, which is essential for the well-being of the population at unbeatable prices, SMEs help to combat inflation; Strong competition is pushing small and medium-sized firms to lower their prices.

\section{Research Methodology}

After completing the theoretical study, we try to support it with an empirical study through questionnaire and bankers interviews.

SMEs are oriented towards external financing represented by a diversified financial environment because of the lack of own funds and in order to support their development. Lebanese SMEs have had almost the same tendency to use the banking sector in most cases, leading to the emergence and development of certain relationships between banks and SMEs [29].
A sample refers to a number of individuals selected from a population to represent it. For example, our survey was carried out on a sample of 110 Lebanese SMEs working in different regions in Lebanon and in various sectors.

In addition to questionnaire, we met qualified bankers from the five top leading banks in Lebanon to highlight lending requirements and procedures, risk assessment and management, approval and rejection decisions related to loans.

A well-prepared work requires very significant resources and facilities from SMEs' managers. In this regard, we have attempted to investigate through direct contact with owners-managers, but we have encountered significant problems. Sometimes it was difficult, if not impossible, to enter certain businesses.

The completion of our survey, makes it easier to us to know the characteristics of SMEs and on the other hand to note that the majority of companies have a spirit of distrust in answering the questions, this case reflects the complications of scientific research in our country.

Our questionnaire contains 17 closed questions with a list of closed answers from which they choose the best one describing their situation and 2 opened questions to let them share their experience and know more about their real situation.

\section{Analysis and Results Discussion}

Through questionnaire with SMEs and interviews with bankers, we were able to sort and classify our data in order to start analyzing results.

\subsection{Latest Innovation for Lebanese SMEs During 2019}

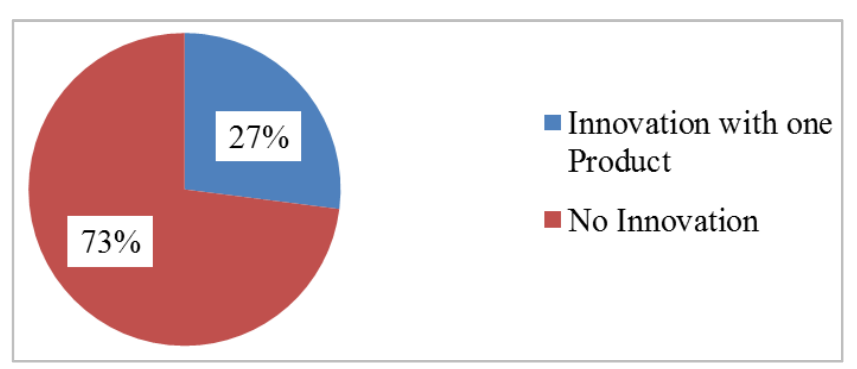

Figure 1. SMEs' innovation in 2019.

Figure 1 represents the innovative practice at SMEs, where $73 \%$ of owners-managers did not take any innovative practice during 2019 and this could be for many reasons, one of them, the wrong perception of innovation/cost. Managers consider investing in innovation could be expensive and for them and part of them consider there is no need to innovate.

$27 \%$ of SMEs did an innovative step during 2019, since they believe that innovation will help the improvement of their business and will assure their growth and sustainability.

SMEs' must start investing in innovation to create more added values, and stay competitive in the market. 


\subsection{Education Level for SMEs' Owners}

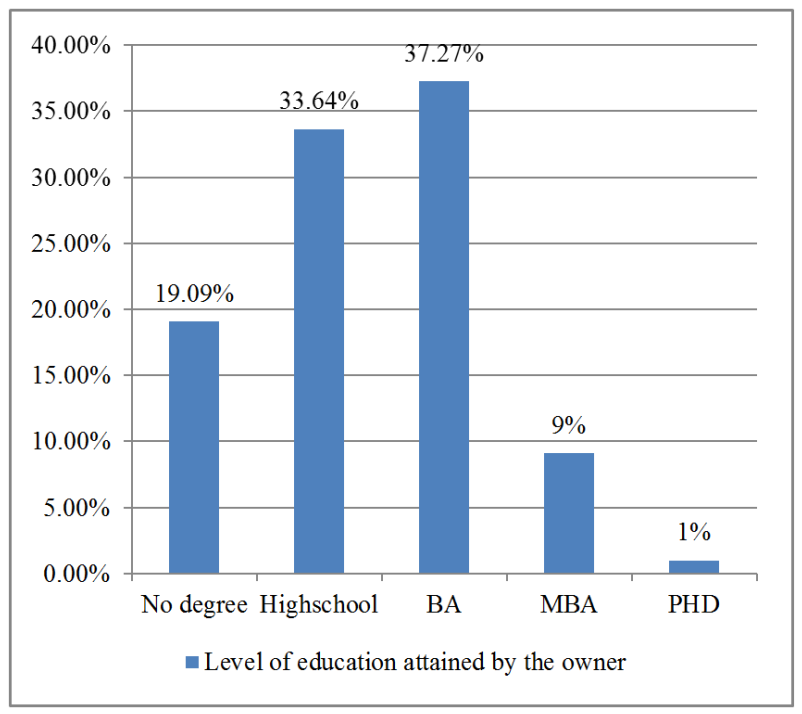

Figure 2. Level of education attained by the owner.

Figure 2 represents the level of education achieved by the owner-manager of an SME.

The highest percentage goes for educated owners with a High school or BA degree (37.27\% of owners-managers SME hold a BA degree and 33.64\% graduated from Highschools). The lowest one of $1 \%$ goes to PHD candidates.

Candidates with high degrees are more interested in academic careers (teachers, lecturers...) instead of creating their own business.

The head of a small business is often the founder. In general, the owner-manager occupies all tasks and does not delegate its authority to other actors. Decisions taken by the owner-manager are generally based on judgments, intuitions, and personal experience. It is important to mention the rate of $19.09 \%$ that represents owners-managers with no academic degree. These owners-managers acquired some managerial skills through experience.

Leadership \& entrepreneurship skills became a necessity to SME's sustainability and performance. Finance skills are also a necessity to be able to track the business activity, read and understand the financial statements especially while applying for credit facility from banks [28].

\subsection{Need for Funding During 2019.}

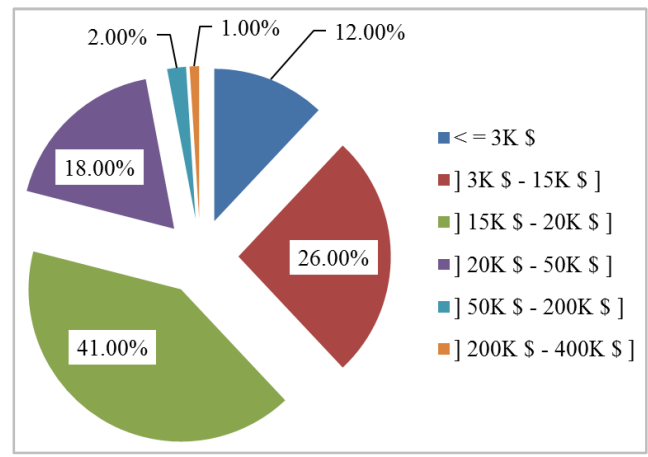

Figure 3. Requested funds by SMEs during 2019.
Figure 3: represents requested funds by SMEs during 2019

Amounts brackets were divided into 6 sections reflecting most available banks' facilities according to competitors and requirements.

The 1st three highest percentages go to loans amounts between $3 \mathrm{~K} \$$ and $50 \mathrm{~K} \$$ and the three lowest percentages go to loans less than $3 \mathrm{~K} \$$ and loans exceeding $50 \mathrm{~K} \$$.

Lebanese SMEs' can benefit from credit facilities up to 3 K\$ from Micro Finance Institution with easy documentation and fast process which clarify the lowest rate for Banks loans less than $3 \mathrm{~K}$. Loans from $50 \mathrm{~K} \$$ to $400 \mathrm{~K} \$$ are more for subsidized loans guaranteed by Kafalat company, the low rate reflect the real situation. Kafalat loans dropped $85 \%$ in the 1 st six months of 2019 as mentioned in the daily Star [30] and after the revolution of October 2019, Banks stopped granting loans during the last 3 months of 2019 [31].

Kafalat is a Lebanese public-interest financial company designed to help small and medium-sized enterprises obtain funding through Kafalat Basic loan up to $200 \mathrm{~K} \$$ or Kafalat Plus loan up to $400 \mathrm{~K} \$$ over 7 years of repayment. It supports small and medium-sized enterprises by providing them with loan guarantees based on feasibility study and business plan. Sectors financed by Kafalat are industry, agriculture, tourism, crafts and new technologies [32].

Kafalat loans are subsidized loans' type. The Lebanese treasury finances interest rate subsidies and it is managed by the Central Bank of Lebanon. SMEs will have the opportunity to expend and develop their activities up to $400 \mathrm{~K} \$$ over 7 years with the guarantee of Kafalat. Banks remain responsible of loan approval, disbursement and follow up.

\subsection{Kafalat Guarantees down by 2019}

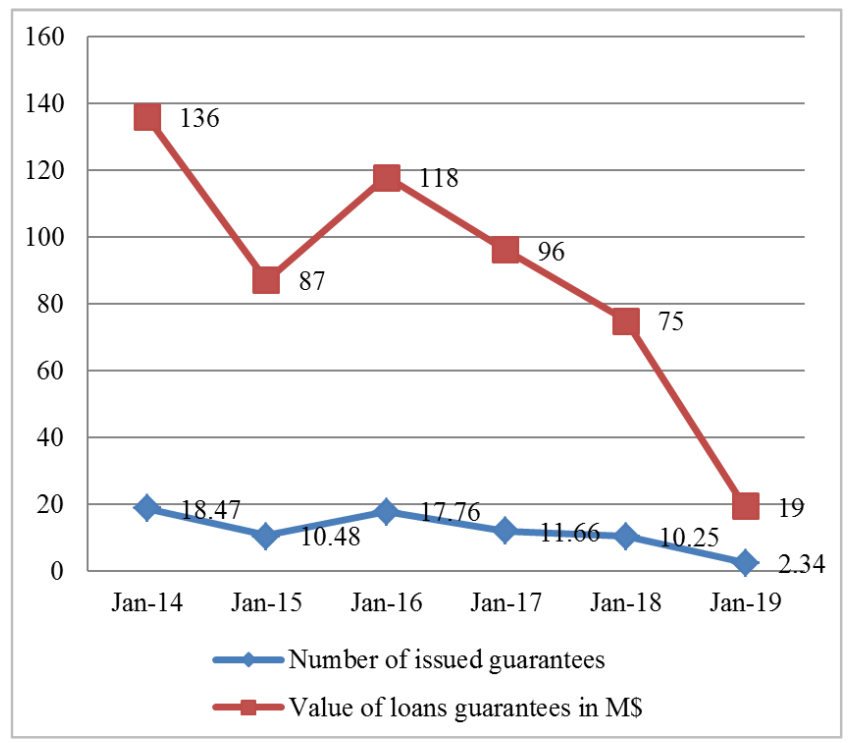

Figure 4. Negative trend for Kafalat guarantees since 2014 till 2019.

Figure 4 shows two curves moving in parallel with a negative trend [33].

The 1st one reflects the number of issued guarantees by Kafalat, which means the number of Kafalat loans disbursed by Lebanese banks. The 2 nd curve reflects the value of loans 
guarantees in M\$. The guarantee ratio is $75 \%$ for Kafalat basic and $85 \%$ for Kafalat Plus, which means that for an SME applying for a Kafalat basic loan for an amount of $100 \mathrm{~K}$, Kafalat will issue a guarantee in the favor of that SME up to 75 K\$. By granting a Kafalat loan, banks are reducing their risk, in fact they share SMEs risks with Kafalat in respect with the percentage of Kafalat's guarantee. For the previous example, in case of repayment failure, Kafalat will handle $75 \%$ of the risk and bank will handle $25 \%$ [32].

The current debt-based financial system prevents SMEs from gaining access to funds. Loans with high amounts are perceived with high risk. Risk-sharing promotes a proactive risk management through the sharing of risks in the economy according to the risk-bearing ability of the participants [34].

\subsection{Loans Rejections}

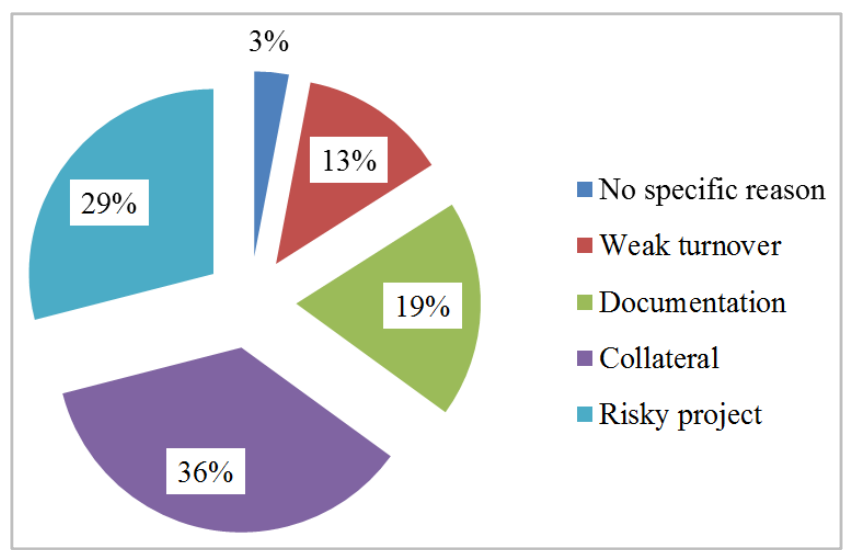

Figure 5. Reasons for rejected loans according to SMEs.

Figure 5 represents reasons of loans rejection according to SMEs' answers. The most reason for rejection was the collateral to take the loan for $36 \%$ of SMEs.

We have grouped all what could be related to collateral as: absence of collateral, value of the collateral does not cover the loan amount and type of collateral that cannot be accept by bank. $29 \%$ of SMEs' declared that their requests were rejected since their projects were considered as risky due to the instability of the country.

According to banks, various reasons could ensure the rejection of loans:

1. Bad information report collected from the central bank \& commercial banks;

2. Returned unpaid checks;

3. Due unpaid loan bills;

4. Too many loans;

5. Age while applying (loans must be settled before the age of 64);

6. Instability sector;

7. Restricted sector;

8. Credit score;

9. Documentation;

10. Weak turnover;
11. No proof of income;

12. No client's contribution or down payment if needed;

13. Insurance company rejection (No life coverage and/or activity cannot be insured);

14. Not satisfying expertise report;

15. Not meeting other eligibility criteria / ratios, depending on loan's type.

For commercial loans as overdraft and direct bills:

1. Indebtedness ratio should be less than 1

2. Monthly bill amount should be less than $25 \%$ of monthly income;

3. Total short term direct facilities at all banks and indirect facilities should be less than $30 \%$ of sales;

4. Total short term direct credit line at all banks should be less than $150 \%$ of the yearly cash flow;

5. Total direct credit line should be less than $60 \%$ of the working capital (current assets - current liabilities);

6. Bank facilities should be less or equal to 5 times the owners' equity

7. Current ratio should exceeds 1.2

Collateral type and value could also be a reason to reject a loan request. The only acceptable assets as collateral are registered plots (lands, buildings) for commercial loans and cars for auto loans. Raw material and other assets as equipment cannot be accepted as collateral.

Registered plots can be mortgaged up to $120 \%$ of loan amount if their values cover at least 2 times banks' facilities, in case of non-settlement of loan the bank can sell the plot without referring to client and get their money back. Mortgages are considered the second way out for loans repayments since the 1st way out is SME's income.

According to interviewed bankers, it's the most secured way and requested for loans' approval during 2019 due to country's instability. Political instability and informal economy can highly affect the growth and development of SMEs and will push banks to reduce the risk as much as they can to avoid loan failure by collecting secured collaterals [35].

It's important to mention that there are some cases where plots are accepted as collateral without being mortgaged. SMEs can suggest a notarized proxy to mortgage if the value of plots covers at least 3 times the facilities. In this case, the original title deed will be kept at bank and in case of default, bank will proceed with plot's mortgage in order to liquidate it and get the money back. Another option is acceptable, the negative pledge if the value of plot exceeds 4 times the facility. It's a simple promise without any obligation, SME promise not to use this plot for any other loan request, and will not be subject of any mortgage or sale action. The last option is the approval on clean basis, without any guarantee, in case SME of with properties free of lien covering at least 5 times the facilities. Some banks used to approve on clean basis loans not exceeding $15 \mathrm{~K} \$$ even with no properties, but for loans on clean basis exceeding $15 \mathrm{~K} \$$, properties free of lien should be presented. 


\subsection{Short and Long Terms Loans}

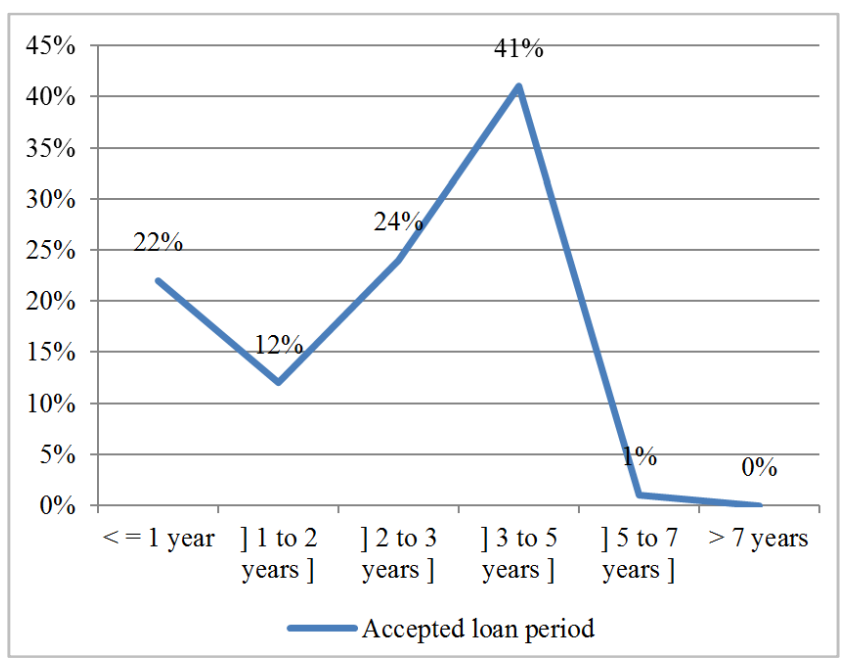

Figure 6. Accepted loan period.

Figure 6 represents loans periods for accepted facilities. The highest rate goes to loans with a maturity between 3 to 5 years scheduled by direct bills on monthly basis. The lowest rates go for loans with a maturity exceeding the 5 years reflecting the drop down of Kafalat loans during 2019.

This study allowed us to identify constraints and find ideas to solve the funding issues.

The limitation of access to funds is due to numerous legal, institutional, administrative, financial, psychological, social, cultural and technological difficulties:

1. The lack of collateral by SMEs;

2. High debit interest rate and lack of liquidity among banking and non-banking financial institutions;

3. Unfavorable attitudes of entrepreneurial culture such as debt aversion and the desire for business autonomy;

4. Some SME owners focus entirely on equity because they believe that debt holds back their business, which limits the rate of start-up businesses, reduces the efficiency of the business, the activities of financial intermediaries and thus the economy.

5. Lack of formal SME definition;

6. SME ignorance of legal texts;

7. SMEs are subject to multiple taxes that are not particularly suited to their small businesses;

8. Tax proliferation;

9. Use of inappropriate technology;

10. Use of unskilled labor;

11. Technology and management inadequacy;

12. Administrative issues, lack of regular accounting and controlled organization prevent SME funding;

13. Lack of procedures transparency in the presentation of credit records, which makes these administrative procedures more complex, a problem of asymmetry of information and the design of the risk factor between the banker and the entrepreneur

14. Following the financial crisis, the new regulatory standards (Basel III) impose much stricter restrictions on banks' capital and liquidity requirements. These new requirements are generally penalizing SME financing.

15. The latest instruction to banks by the central bank to raise capital by up to $20 \%$ by the end of June 2020 [36] and the lack of liquidity at banks after the high demand on cash after the revolution of October 2019 [31].

16. Fragile infrastructure that harms firms' competitiveness by increasing their production costs.

To solve the problems revealed in our empirical study and this is what companies have long been asking for and looking for building capacity, performance, growth, sustainability, management techniques, expertise and training [37], [38]:

1. Assisting SMEs to access foreign markets, to acquire new technologies and to innovate.

2. Facilitating SME access to public procurement

3. Providing assistance for SME networking;

4. Spread by all appropriate means, SME legislation and regulation

5. Collect and disseminate information on the role of small and medium-sized enterprises, their contribution to the national economy and the development of their business

6. Monitoring and evaluating actions and programs to promote SMEs

7. Prepare all administrative procedures necessary to implement investment projects in all sectors

8. Create a business intelligence system to capture and explore various investment projects at the regional, national and international levels

9. Reducing the cost of discipline in different regulatory areas

10. Reduce the time needed to start a business

11. Rules for employment protection related to individual and collective redundancies of employees on an indefinite contract

12. Reduce the complexity of licensing systems, standardize national licensing requirements

13. Improving the transparency and economic efficiency of administrative regulation

The current financial system is inadequate or poorly equipped to meet the multiple financial needs of SMEs on their own.

Small and medium-sized firms with a strong financial structure, a clearly defined market in which they are already involved, with growth prospects, current and future profitability is clear and whose promoters can offer acceptable real or personal guarantees are likely to find financing from banks.

However, the implementation of sustainable financing also requires a number of prerequisites and supportive measures by stakeholders.

Towards public authorities, it is necessary to:

1. Implement guidelines and standards for work programs

2. The government should develop security funds as intermediaries between banks and medium-sized enterprises, so that these enterprises have easy access to conventional commercial bank credit, making it easier to grant credit to unsecured economic operators

3. A favorable tax system

4. Reducing the administrative charges for young 
businesses, lowering legal barriers to entry

5. Ensuring political stability and security stability

6. Create a competitive investment climate

7. Create a database to help investors

8. Deliver leadership training to empower managers' skills

At the central bank level \& financial institutions:

1. Increase subsidized loans to support SMEs

2. Administrative costs must be acceptable and other conditions applicable to customers

3. Encourage leasing to finance investments by medium-sized enterprises. Indeed, leasing as a financing tool provides more flexible terms without requiring significant collateral On SMEs level:

1. Tracking and keeping records for business work

2. Prepare balance sheet and income statement on yearly basis

3. Have a sense of responsibility, respect for commitments

4. Improve the overall quality of the workforce

5. Assure a good working history with banks.

6. Start using digital technologies that offers potential for further streamlining of procedures, the Internet authorizations has simplified the process of establishing and operating a business.

\subsection{Lending Activity}

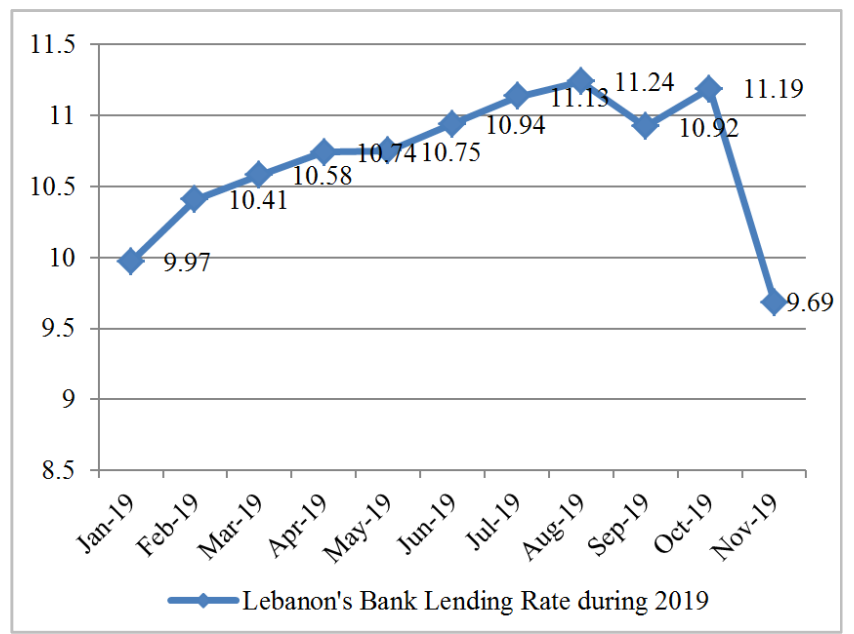

Figure 7. Lebanon's Bank Lending Rate during 2019.

Figure 7 represents Lebanon's bank lending rate during 2019 [39]. The curve has a positive trend; started with $9.97 \%$ for lending rate on January 2019 and reach a peak on August 2019. This can be explained by the summer season where SMEs try to expand their activities by new investments through banks financing. The curve shows a drop on October 2019 explained by Lebanese revolution and followed by banks restrictions on banks transactions.

\section{Conclusion}

In a company's life, financing is an important task, to ensure the operational and investment work in order to support the SME's growth and sustainability [40].

Source of financing can be internal or external. Internal financing is self-financing, while external financing focuses on the role of financial markets formed by financial institutions [41].

Given the importance that SMEs occupy in the economy, especially in Lebanon, SMEs have a key role in the development of our economy, through the reduction of the unemployment rate, the poverty rate [42].

Studies and results show that small and medium-sized enterprises have many weaknesses and that for several reasons, internal, i.e. professional or external, related to their environment. The conditions for their continuity and development are certainly linked to the legislative, financial and social context of the country.

The financing problem is the main obstacle to SME development either because of the lack of internal or external funding or because of the complexity of the procedures to be followed for loans approval [43]. Similarly, globalization of the economy (production systems, markets, goods and services, capital and labor) imposes more difficult management (planning and control) rules on enterprises, groups, sizes and sectors.

In the end, SMEs' access to bank financing is an important activity for the development of this sector and for the economy [44], [45]. To make this happen, both sides, banks and SMEs, must make considerable efforts to strengthen corporate financing [46]. Moreover, we must provide ideas for contributing to the development of the banking and financial sector in our country.

The balance of the financial structure is highly requested, investment needs must be financed by direct bills as long-term debt and the operational needs to be financed by short-term debts as overdrafts, suppliers, direct bills for less than on year depending on the inventory type. A bad choice can lead the company to fail, especially when managers try financing their investment needs by overdraft facility to avoid scheduled payments [16].

Since Oct 17th 2019, the Lebanese revolution, new limits and restrictions were made by the Lebanese banks. Lending became complicated due to lack of liquidity in banks. Asking for loans is also complicated due to the recession in the country, high unemployment rate, closure of large firms, difficulty in money transfers, limited transactions amounts via banks, black market for exchange rate... [47] what make us curious to ask, can SMEs face all these challenges? Are there opportunities to survive during a financial collapse?

\section{References}

[1] Wolf, M. (2018) The global economic recovery is real but fragile

https://www.ft.com/content/532f1142-4163-11e8-93cf-67ac3a $6482 \mathrm{fd}$

[2] Karadag, H. (2016) The Role of SMEs and Entrepreneurship on Economic Growth in Emerging Economies within the Post-Crisis Era: an Analysis from Turkey. Journal of Small Business and Entrepreneurship Development. 4. 22-31. 10.15640/jsbed.v4n1a3. 
[3] Gancarczyk M. \& Zabala-Iturriagagoitia J.(2015). The Process of the Growth of Small and Medium-Sized Enterprises (SMEs). Journal of Entrepreneurship, Management and Innovation. 11. 3-24. 10.7341/20151141.

[4] Atul, R. (2019) Five sources of funds to fast track SME growth https://www.wfglobal.org/five-sources-of-funds-to-fast-track-s me-growth/

[5] The Economist (2019), Dec 12th 2019 Edition, As Lebanon's economy drowns in debt, Syria's begins to sink as well. https://www.economist.com/middle-east-and-africa/2019/12/1 2/as-lebanons-economy-drowns-in-debt-syrias-begins-to-sinkas-well

[6] Sull, D. (1999) Why Good Companies Go Bad, Harvard Business Review, July August issue, https://hbr.org/1999/07/why-good-companies-go-bad

[7] Naimy V. (2011). Financing Problems Faced By The Lebanese SMEs: An Empirical Study. International Business \& Economics Research Journal (IBER). 3. 10.19030/iber.v3i1.3652.

[8] Badugu D. \& Tripathi V. (2016) Micro-Finance Research Structure Studies: The Microfinance Structures, Microfinance Systems, and Microfinance Institutions, Such as the Social, Economic Empowerment of the Poor International Journal of Business and Applied Social Science Vol. 2, No. 2, February, 2016 - s.ssrn.com/sol3/papers.cfm?abstract_id=2942527

[9] Alessandrini P., Presbitero A. \& Zazzaro A. (2009): Banks, distances and firms' financing constraints. Review of Finance 2009, 13 (2): 261-307.

[10] Campanella, F., Del Giudice, M. \& Peruta, (2013) M. R. D. The role of information in the credit relationship. J Innov Entrep 2, 17 (2013). https://doi.org/10.1186/2192-5372-2-17

[11] Demiroglu, Ch., James, C., \& Kizilaslan, A. (2012). Bank lending standards and access to lines of credit. Journal of Money, Credit and Banking, 44 (6), 1063-1089.

[12] Schmukler S. \& De La Torre A. \& Martinez Peria M. (2008). Bank Involvement with SMEs: Beyond Relationship Lending. Journal of Banking \& Finance. 34. 2280-2293. 10.1016/j.jbankfin.2010.02.014.

[13] Prager R. \& Wolken J. (2008). The Evolving Relationship between Community Banks and Small Businesses: Evidence from the Surveys of Small Business Finances. Finance and Economics Discussion Series. 2008. 10.17016/FEDS.2008.60.

[14] Abdesamed K. \& Abd Wahab K. (2014). Financing of small and medium enterprises (SMEs): Determinants of bank loan application. African Journal of Business Management. 8. 717-727. 10.5897/AJBM2013.7222.

[15] Rexhepi Mahmutaj L. (2014). The impact of innovation in SME's performance. Horizons / Horizonti. 12. 195-206.

[16] Beck T. \& Demirguc-Kunt A. \& Martinez Peria M. (2008). Bank Financing for SMEs Around the World: Drivers, Obstacles, Business Models, and Lending Practices. The World Bank, Policy Research Working Paper Series.

[17] Hauptmann C. (2017). Corporate Sustainability Performance and Bank Loan Pricing: It Pays to Be Good, but Only When Banks Are Too. Saïd Business School WP 2017-20. http://dx.doi.org/10.2139/ssrn.3067422

[18] Laib, Y. (2013). Determinants of bank financing for small and medium enterprise. Gestion 2000, volume 30 (3), 29-47. doi: 10.3917/g2000.303.0029.

[19] Belás, J.; Mišanková, M.; Schönfeld, J.; Gavurova, B. (2017). Credit risk management: financial safety and sustainability aspects. Journal of Security and Sustainability Issues, 7 (1), 79-93. https://doi.org/10.9770/jssi.2017.7.1(7)

[20] Aven T. (2015). Risk assessment and risk management: Review of recent advances on their foundation. European Journal of Operational Research. 10.1016/j.ejor.2015.12.023.

[21] Al Arabiya, (2019) Lebanon's Central Bank governor says country is in a 'dollarized economy' http:/english.alarabiya.net/en/business/economy/2019/11/11/ Lebanon-s-Central-Bank-Governor-says-country-is-in-a-dollar ized-economy-.html

[22] Tabellini G. (2005). The Role of the State in Economic $\begin{array}{lll}\text { Development. } & \text { Kyklos. } & \text { 283-303. }\end{array}$ 10.1111/j.0023-5962.2005.00289.x.

[23] Sayeed A. \& Abbasi Z. (2015). "The role of central banks in supporting economic growth and creation of productive employment: the case of Pakistan," ILO Working Papers 994874753402676, International Labour Organization

[24] Bittencourt M. \& Gupta R. \& Stander L. (2014). Tax evasion, financial development and inflation: Theory and empirical evidence. Journal of Banking \& Finance. 41. 194-208. 0.1016/j.jbankfin.2014.01.009.

[25] Abdulsaleh, A. M., \& Worthington, A. C. (2013). Small and medium-sized enterprises financing: A review of literature. International Journal of Business and Management, (14), 36.

[26] Hamdar B. \& Najjar R. \& Karameh K. (2017). The Lebanese Perception of the Impact of Small \& Medium Enterprises (SMEs) on the National Economy. Journal of Economics and Public Finance. 3. 330. 10.22158/jepf.v3n3p330.

[27] Malaeb O. (2018). Small and Medium Enterprises in Lebanon: Obstacles and Future Perspectives.

[28] Obaji N. \& Olaolu D. \& Jumbo D. (2019). Entrepreneurial Skills as Catalyst for Sustainable SME Performance. 10.22624/AIMS/iSTEAMS-2019/V16N1P6.

[29] Asrawi, F. (2010). Assesing the business environment for small and medium size enterprise in Lebanon. International Journal of Business and Public Administration. 7. 103-116.

[30] The Dialy Star Lebanon (2019): Kafalat loans drop 85 percent in first six months of 2019 https://www.dailystar.com.lb/Business/Local/2019/Aug-15/48 9673-kafalat-loans-drop-85-percent-in-first-six-months-of-201 9.ashx

[31] Chaaban J. (2019) Why aren't lebanese banks giving back your money http://beirut-today.com/2019/11/08/arent-lebanese-banks-givin g-back-money/

[32] Kafalat (2020) Kafalat description http://kafalat.com.lb/about-us

[33] Blom Invest Bank (2019) Value of Kafalat Guarantees https://blog.blominvestbank.com/29313/value-of-kafalat-guar antees-down-by-february-2019-to-2-34m/

[34] Lajis S. (2017) Risk-Sharing Securities: Accelerating Finance for SMEs. Islamic Economic Studies, Vol. 25, No. 2, 2017. Available at SSRN: https://ssrn.com/abstract $=3150197$ 
[35] Elbahnasawy N. \& Ellis M. \& Adom A. (2016). Political Instability and the Informal Economy. World Development. 85. 10.1016/j.worlddev.2016.04.009.

[36] Hadchiti S. (2019) BDL Instructs Banks to raise capital by up to $20 \%$ by the end of June 2020 https://blog.blominvestbank.com/31561/bdl-instructs-banks-to -raise-capital-by-up-to-20-by-the-middle-of-2020/

[37] Drucker, P. (2020). Our entrepreneurial economy. Harvard Business Review. 62. 59-64.

[38] Pansiri J. \& Temtime Z. (2008). Assessing managerial skills in SMEs for capacity building. Journal of Management Development. 27. 251-260. 10.1108/02621710810849362.

[39] CEIC (2020) Lebanon Bank Lending Rate https://www.ceicdata.com/en/indicator/lebanon/bank-lending-r ate

[40] Wlodarczyk B., Szturo M., Ionescu G., Firoiu D., Pirvu R., \& al.. (2018) The impact of credit availability on small and medium companies. Entrepreneurship and Sustainability Issues, Entrepreneurship and Sustainability Center, 2018, 5 (3), pp. 565-580. ff10.9770/jesi.2018.5.3(12)ff.ffhal-01773998f

[41] Abbasi W. \& Wang Z. \& Abbasi D. (2017) Potential Sources of Financing for Small and Medium Enterprises (SMEs) and Role of Government in Supporting SMEs URL: https://doi.org/10.15640/jsbed.v5n2a4
[42] Capasso S. \& Jappelli T. (2011). Financial Development and the Underground Economy. Journal of Development Economics. 101. 10.1016/j.jdeveco.2012.10.005.

[43] Beck T. \& Demirguc-Kunt A. \& Laeven L. \& Maksimovic V. (2006). The Determinants of Financing Obstacles. Journal of International Money and Finance. 25. 932-952. 10.1016/j.jimonfin.2006.07.005.

[44] Arzeni, S., Cusmano, L., \&Robano, V. (2015). Access to Finance for SMEs and Entrepreneurs: Trends and Policies in OECD Countries. In Public Private Partnerships for Infrastructure and Business Development (pp. 189-220). Palgrave Macmillan US

[45] Beck T. \& Demirguc-Kunt A. (2006). Small and Medium-size Enterprises: Access to Finance as a Growth Constraint. Journal of Banking \& Finance. 30. 2931-2943. 10.1016/j.jbankfin.2006.05.009.

[46] Shihadeh F., Naradda Gamage S. \& Hannoon A. (2019) The causal relationship between SME sustainability and banks' risk, Economic Research-Ekonomska Istraživanja, 32: 1, 2743-2760, DOI: 10.1080/1331677X.2019.1655465

[47] Amlôt M. (2019) Lebanon's black market exchange rates soars up to 50 pct over USD peg http://english.alarabiya.net/en/business/economy/2019/11/26/ Lebanon-s-black-market-exchange-rates-soars-up-to-50-pct-o ver-USD-peg.html 